\title{
THE NATURE AND DETERMINANTS OF HIGH-VALUE HOUSEHOLD DEPOSITS IN THE EURO AREA*
}

\begin{abstract}
This paper analyses the occurrence and nature of high-value deposits in selected euro area countries and the determinants of a household's propensity to possess them. The analysis is conducted on household-level data and based on logistic regression. Due to the rarity of high-value deposits in euro area households, the sample of households surveyed is balanced in accordance with G. S. Maddala's approach. The results reveal considerable diversification in high-value deposits as a proportion of total deposits in euro area households. Some of the features of households and reference persons, such as attitudes to financial risk, saving aims, overall investment preferences, and the priority accorded to deposits compared to other financial assets, suggest that highvalue deposits are of a long-term nature. The study finds that wealth, and certain sociodemographic characteristics, have a statistically significant influence on the likelihood of holding high-value deposits.
\end{abstract}

Keywords: high-value household deposits, deposit outflows, credit institution funding, liquidity standards.

JEL Classification: G21, D14, G01.

\section{Introduction}

Following the recent financial crisis, greater importance has been attached to stable funding for credit institutions. The new approach has been reflected in European Union regulations developed since 2013.

Katarzyna Kochaniak, Cracow University of Economics, Department of Finance, Rakowicka 27, 31-510 Kraków, Poland, e-mail: katarzyna.kochaniak@uek.krakow.pl

* This paper presents the results of a research project conducted with the financial support of the National Science Centre in Poland (grant number: DEC-2013/11/D/HS4/04056). The analysis is based on data provided by the Eurosystem Household Finance and Consumption Survey. 
The introduction of the Liquidity Coverage Ratio (LCR) and the Net Stable Funding Ratio (NSFR) provides a powerful indication of the importance of stable funding for credit institutions in both the short and long run. Funding must be sufficient to ensure that, even in periods of stress, these institutions perform safely. EU provisions (EU 2013a, 2013b) concentrate on retail deposits and on household deposits in particular. Not all deposits are, however, defined in the same way. The shocks experienced in 2008-09 revealed certain features of deposits that make them more vulnerable. One such feature is that deposits of at least EUR 500,000 are regarded as very high value deposits. Regardless of local resistance to shocks, local standards of living, or the financial investment preferences of local households, this threshold now applies throughout the EU. Does it make sense to apply uniform regulation to a group of heterogeneous countries?

Based on household-level data from the Eurosystem Household Finance and Consumption Survey (HFCS), the aim of this paper is to investigate high-value household deposits and their determinants in 15 euro area countries. Respondents' propensity to possess deposits of this kind are analysed using a logistic regression model with reference to Maddala's approach to balancing the sample in the case of rare events (Maddala 2006).

Attempts are made to find answers to the following questions:

1. What proportion of household deposits in the euro area countries are high-value deposits?

2. With respect to financial standing and socio-demographic features, do the owners of high-value deposits form a single group in the euro area?

3 . What are the determinants of a household's propensity to possess high-value deposits in the euro area?

The following hypothesis is tested: Households with high-value deposits are associated with a particular financial standing and with specific socio-demographic features. Though the frequency of households with high-value deposits is not identical for each state in the euro area, it is still possible to identify common sets of characteristics which influence their propensity to possess high-value deposits. It may be the case that, while the EU's uniform regulatory framework makes domestic credit institutions more resilient, the benefits of the "one size fits all" approach are limited due to heterogeneity.

Following the introduction, the paper presents a survey of the related literature, before proceeding to an account of the regulatory approach to high-value household deposits. There follows a description of the data and methodology employed to study the occurrence of high-value household 
deposits in the euro area and the determinants of households' propensity to possess them. The results are then set out and conclusions are drawn.

\section{Related Literature}

The literature on the funding stability of credit institutions discusses matters of importance during short-term crises and over longer periods of time. They include sources of funding for banks (Diamond \& Rajan 2001, Borio 2009, Huang \& Ratnovski 2011), financial assets held by households (Du Caju 2013), the connections between the limits of deposit insurance systems (DIS) and the way that individuals perceive risk (Karas, Pyle \& Schoors 2013, Brown, Guin \& Morkoetter 2013, Acharya \& Mora 2015), the relationship between deposit outflows and incidents of financial turmoil (Cussen, O'Leary \& Smith 2012), the links between downturns on commercial paper markets and deposit transfers (Pennacchi 2006, Gatev, Schuermann \& Strahan 2009), the impact of interest rates on deposit outflows (Acharya \& Mora 2012) and the correlation between deposit outflows and loan availability (Acharya, Almeida \& Campello 2013). Some papers compare countries according to the purposes of household saving, with a focus on deposits as a component of household financial asset portfolios (Teppa et al. 2015).

In view of the implementation of the EU's uniform post-crisis regulations, the question of the stability of household deposits has lost none of its relevance. The paper is among the first to investigate the uniform regulation from the perspective of high-value household deposits and their determinants.

\section{The Regulatory Approach to High-Value Household Deposits}

The EU regulatory framework on the funding stability of credit institutions was based on the Basel III Accord of December 2010 (BCBS 2010). For LCR, it distinguished stable deposits as those with low rates of outflows of $5 \%$ or $3 \%$ and less stable deposits as those with outflow rates of $10 \%$ (BCBS 2013). In both cases, the run-offs were assumed as minimum floors. The adoption of increased outflow proportions was left to individual jurisdictions, which would have a sharper picture of the behaviour of local depositors in a period of stress. Though the high-value deposits could be counted among the less stable, the Basel Committee on Banking Supervision did not indicate any particular threshold for them (BCBS 2013). 
The framework of the EU regulations on the funding stability of credit institutions is available in the in the package "Capital Requirements Directive IV and Capital Requirements Regulation" issued in 2013. The quality of funding was discussed within the terms of LCR and NSFR.

In 2013, the package was supplemented by the European Banking Authority (EBA) guidelines on the assessment of LCR at the EU credit institutions (EBA 2013a). They listed the factors determining higher outflows of retail deposits, pointing out the significance of their value. If the sum of deposits held by one client at one entity was in excess of EUR 100,000 , or above the limit of a local deposit guarantee scheme (and in any case no higher than EUR 500,000), the deposit was to be regarded as of high value. The EBA also proposed a category of very-high deposits exceeding EUR 500,000. The conclusion could be drawn that there was a high risk of outflows of high-value deposits and a very high risk of outflows of very high value deposits.

The detailed information regarding less stable retail deposits, including household deposits, in periods of stress was presented by the European Commission (EC) in its delegated act in 2014 (EU 2015). Deposits exceeding EUR 500,000 were defined as high-value deposits and presented as the ones liable to increased volatility. The additional category proposed by the EBA was therefore not adopted.

The evolution of the EU definition of deposits with increased outflows, and the lack of formal empirical analysis in the individual countries regarding this issue, raised doubts about the appropriateness of the adopted limit of EUR 500,000 and thereby prompted the present study.

\section{Data and Methodology}

Fifteen euro area states were studied: Austria, Belgium, Cyprus, Finland, France, Germany, Greece, Italy, Luxembourg, Malta, the Netherlands, Portugal, Slovakia, Slovenia and Spain. They were selected due to the availability of the required information. The study was based on quantitative and qualitative data from the Eurosystem HFCS and was focused on households possessing high-value deposits. It should be noted that the database did not provide information on whether the sums above EUR 500,000 were held in one or more credit institutions. The sets of variables were organised as follows: 
1. Quantitative, describing the household's:

- size $(\mathrm{N})$ : number of household members (NHM), number of members in employment (NME), number of members aged 16+ (NM16+);

- wealth (W): gross income (WGI), net wealth ${ }^{1}$ (WNW), high-value deposits (WHD), value of sight deposits (WSD), value of savings deposits (WVD), value of total real assets (WRA) such as real estate, vehicles and valuables; value of total financial assets excluding deposits (WFA);

2. Qualitative ${ }^{2}$, describing the household's:

- investment attitude (IA): willing to take substantial financial risks and expecting to earn substantial returns (IA1), willing to take above average financial risks and expecting to earn above average returns (IA2), willing to take average financial risks to earn average returns (IA3), unwilling to take any financial risks (IA4);

- reasons for saving (S): purchase of own home (SPH), other major purchases (SOP) such as residences, vehicles and furniture; setting up a private business or financing investments in an existing business (SFB), investing in financial assets (SFA), providing for unexpected events (SUE), paying off debts (SPD), provision for old-age (SOA), education/support for children and grandchildren (SES), bequests (SBQ), taking advantage of state subsidies (SAS);

- wealth $\left(\mathrm{W}^{\prime}\right)$, possession of: mutual funds (W'MF), publicly-traded shares (W'TS), bonds (W'BO), collateralised loans (W'CL), gifts or an inheritance (W'GI);

3. Quantitative, describing a reference person:

- age (A);

4. Qualitative, describing a reference person:

- the highest level of education completed (E): tertiary (ETR), upper-secondary (EUS), lower-secondary (ELS), primary or below (EPR);

- marital status (M): married (MAR), single/never married (MSI), consensual union on legal basis (MCU), widowed (MWI), divorced (MDI);

- labour status (L): doing regular work for pay/self-employed/working in family business (LSW), on sick leave, maternity leave or another type of leave (LSL), unemployed (LSU), student/pupil/unpaid intern (LSS), retired or in early retirement (LSR), permanently disabled (LSD), compulsory

\footnotetext{
${ }^{1}$ Net wealth is defined as the difference between total (gross) assets and total liabilities. Total assets consist of real assets and financial assets.

${ }^{2}$ The qualitative variable takes the value 1 or 0 to indicate the presence or absence of a categorical effect that can be expected to change the outcome.
} 
military service or equivalent social service (LSM), fulfilling domestic tasks (LST), other: not working for pay (LSO);

- gender (G): male (GMA); female (GFE);

- wealth ( $\left.\mathrm{W}^{\prime}\right)$, possession of: public pension plans (W'PP), a voluntary pension scheme ( $\left.\mathrm{W}^{\prime} \mathrm{VP}\right)$;

5. Qualitative, describing country of residence (C): Austria (AT), Belgium (BE), Cyprus (CY), Germany (DE), Spain (ES), Finland (FI), France (FR), Greece (GR), Italy (IT), Luxembourg (LU), Malta (MT), the Netherlands (NL), Portugal (PT), Slovenia (SI), Slovakia (SK).

The first part of the study elicited answers to the following questions: What is the position of large deposits among all household deposits in the euro area countries? Regarding their financial standing and socio-demographic features, do the owners of high-value deposits represent a single group in the euro area? A number of the above variables were used to identify the characteristics of households and reference persons with high-value deposits. The variables also had the potential to reveal whether the deposits were stable or unstable. The variables from the following sub-sets were applied: size (N): NHM, NME; wealth (W and $\mathrm{W}^{\prime}$ ): WRA, WFA, WHD, WSD, WVD, W'GI; declared attitudes to risk (IA): IA 1-4; saving aims (S): SPH, SOP, SFB, SFA, SUE, SPD, SOA, SES, SBQ, SAS; age of reference person $(\mathrm{A})$.

The second part of the study attempted to answer the following question: What are the determinants of the propensity of euro area households to hold large deposits? A number of variables were employed to identify them. As well as numerical variables: wealth (W) and household size (N), these were dummies from the following subgroups: age (A), education (E), gender $(\mathrm{G})$, declared attitudes to risk (IA), labour status (L), marital status (M), countries (C) and wealth ( $\left.\mathrm{W}^{\prime}\right)$. The variables were applied in the logit model described by the following formula:

$$
y_{i}^{*}=\beta_{0}+\sum_{j=1}^{k} \beta_{j} x_{i j}+u_{i},
$$

where: $y_{i}^{*}$ - latent variable; $x_{i j}$ - explanatory variables $(i=1,2, \ldots, n ; j=1$, $2, \ldots, k) ; \beta_{j}$ - regression parameters $\left(\beta_{0}-\right.$ constant $) ; u_{i}$ - random component.

All of the observations of high-value deposits were enabled to form a dummy $Y$, which represented the fact that households owned high-value deposits (if the household has a large deposit $Y=1$, otherwise $Y=0$ ). Hence, the variable $y_{i}^{*}$ could be defined as a household's propensity to hold a deposit exceeding EUR 500,000 (Maddala 2014) or as the probability that 
a household possesses a high-value deposit resulting from the occurrence of particular characteristics (Ulman 2011).

The first wave of HFCS includes 265 households with large deposits. The significant difference between that number and the remaining households, which did not possess such deposits, prompted the decision to balance the sample (Maddala 2006). As a result, a random subset of a further 265 households, this time without large deposits, was taken. The final sample considered in the analysis therefore consisted of 530 households.

Both types of variable - quantitative and qualitative - were applied in this part of the study. Some of the quantitative variables were converted into categorical variables, that is: total real assets (WRA), gross income (WGI), net wealth (WNW), total financial assets excluding deposits (WFA) and age of reference person (A) (Podolec, Ulman \& Wałęga 2008). As the levels of these features were highly diverse, they were divided into three categories: low, medium and high. The boundaries of the assignment of characteristics to a particular category were determined by the values of quantile $0.33\left(q_{0.33}\right)$ and quantile $0.66\left(q_{0.66}\right)$. The levels were defined as follows (Table 1): low level of the feature: $x<q_{0.33}$; medium level of the feature: $q_{0.33} \leq x \leq q_{0.66}$; high level of the feature: $x>q_{0.66}$.

Table 1. Numerical Characteristics of Selected Household Characteristics (in EUR)

\begin{tabular}{c|c|c}
\hline & $q_{0.33}$ & $q_{0.66}$ \\
\hline WRA & 245,000 & 979,300 \\
\hline WGI & 38,100 & 97,100 \\
\hline WNW & 268,992 & $2,008,625$ \\
\hline WFA & 1,320 & 139,444 \\
\hline
\end{tabular}

Source: author's own calculations based on Eurosystem HFCS data.

Table 1 shows that variables for $33 \%$ of the euro area households depicted values not exceeding the quotations for $q_{0.33}$, while the remaining $67 \%$ depicted at least these sums. The quantile $q_{0.66}$ means that the characteristics of $66 \%$ of the households represented the values up to the specified level and the remaining $33 \%$ of households represented at least these values. In the next step, the categorical variables were converted into dummies, which were applied in the logit model. They referred to the low and high levels of the characteristics. The medium level was adopted as the base for comparison. As a consequence, total real assets (WRA) were converted into: 
WRA LOW with a value of 1 when WRA $<245,000$ and 0 in all other cases; WRA MEDIUM with a value of 1 when $245,000 \leq \mathrm{WRA} \leq 979,300$ and 0 in all other cases; WRA HIGH with a value of 1 when WRA > 979,300 and 0 in all other cases. The remaining variables, except age (A), were treated in the same way. The quantiles for age indicated only the boundaries deciding the assignment of households to particular categories. The variable A LOW took a value of 1 when $\mathrm{A} \leq 50$ years old and 0 in all other cases; A MEDIUM took a value of 1 when $\mathrm{A} \leq 65$ years old and 0 in all other cases; $\mathrm{A}$ HIGH took a value of 1 when $\mathrm{A}>65$ years old and 0 in all other cases.

Parameter estimates from multiple regression models ${ }^{3}$ were used as initial values of the parameters in the logit models.

\section{Results}

The first part of the study analysed the significance of high-value deposits (WHD) and the characteristics of the depositors in individual countries.

The data disclosed that only small proportions of households declared high-value deposits in the national samples which, in the Slovakian and Slovenian cases, revealed no high-value deposits whatsoever. The proportion of households holding high-value deposits was greatest in the Spanish case $(2 \%)$. These proportions were consistent with the share of all high-value deposits in total deposits at the domestic level (Figure 1). In some member states, however, the impact of high-value deposits on the overall total was significant. In Spain, for example, high-value deposits constituted $41.3 \%$ of total household deposits, while they made up $25.9 \%$ of total household deposits in Belgium and $22.7 \%$ in Luxembourg. The proportion of high-value deposits in total deposits was, at 10-15\%, also notable in Cyprus, France, Austria and Portugal. These results indicate that high-value deposits play an important role in the funding of selected MFI sectors in the euro area. Building detailed profiles of the people who hold them could be the key to understanding the volatility of high-value deposits in the individual euro area states.

There was considerable diversification in the amounts of high-value deposits held in the euro area (Table 2), which was expressed in a coefficient of variation (CV) of 12-124\%. The highest amounts were noted in Belgium and Luxembourg and the lowest in Cyprus and Finland. The median for high-value deposits varied from EUR 550,000 in Cyprus to EUR 833,357 in Spain. The minimum levels were close to the adopted threshold almost

\footnotetext{
${ }^{3}$ The explanatory variables were selected based on stepwise regression.
} 
everywhere, while the maximum levels lay in a range from EUR 700,000 in Cyprus and EUR 7,050,000 in Spain.

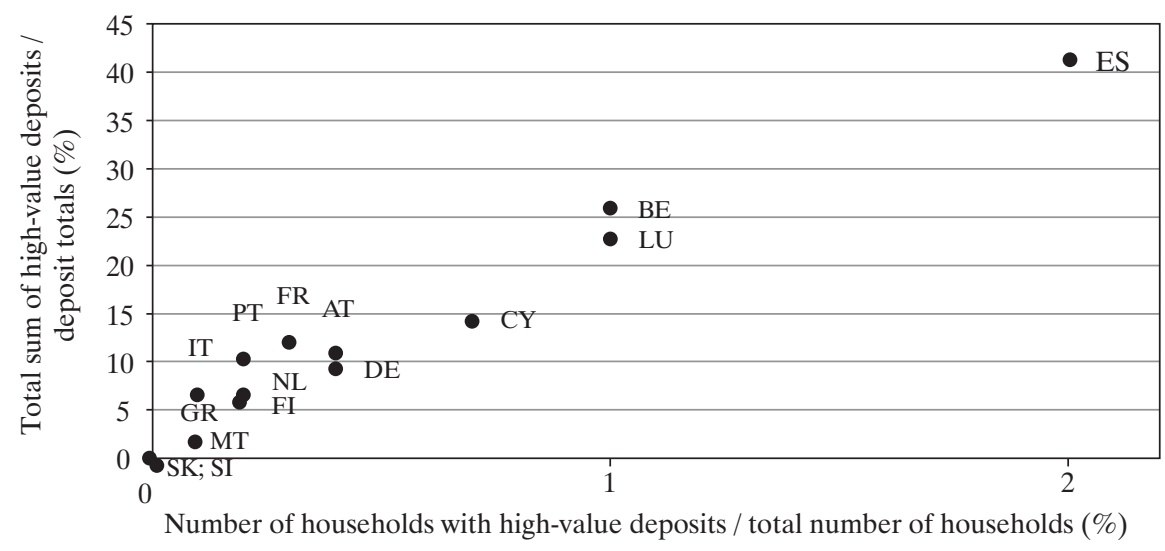

Fig. 1. Sum of High-value Household Deposits/Household Deposit Totals (\%) and Number of Households with High-value Deposits/Total Number of Households (\%) in Individual Eurozone Countries

Source: author's own study based on Eurosystem HFCS data.

It can be assumed that at least some proportion of the diversity between countries was the result of the heterogeneity of households, which was described by characteristics such as size (NHM, NME), wealth (WRA, WFA, WSD, WVD, W'GI), declared attitudes to risk (IA), saving aims (S) or age of the reference person (A). The variables are summarised in Table 3 and Table 4.

The average number of household members did not exceed three in any of the countries studied. In only a few of them, however, was there more than one person in employment. The most frequent attitudes to risk were "willing to take average financial risks" and "unwilling to take any financial risks". These outlooks could suggest that high-value deposits are stable. If that were so, the regulatory approach may not be appropriate. The most common saving aims of the households surveyed - provision for old-age and bequests - also revealed the long-term nature of the deposits. The households demonstrated considerable diversification in the total real assets and total financial assets they held. It should be noted that past gifts and inheritances accounted for the financial position of a large proportion of households, which was therefore not the result of wise investment decisions. Deposits dominated financial assets in Belgium, Finland, France, Italy, 


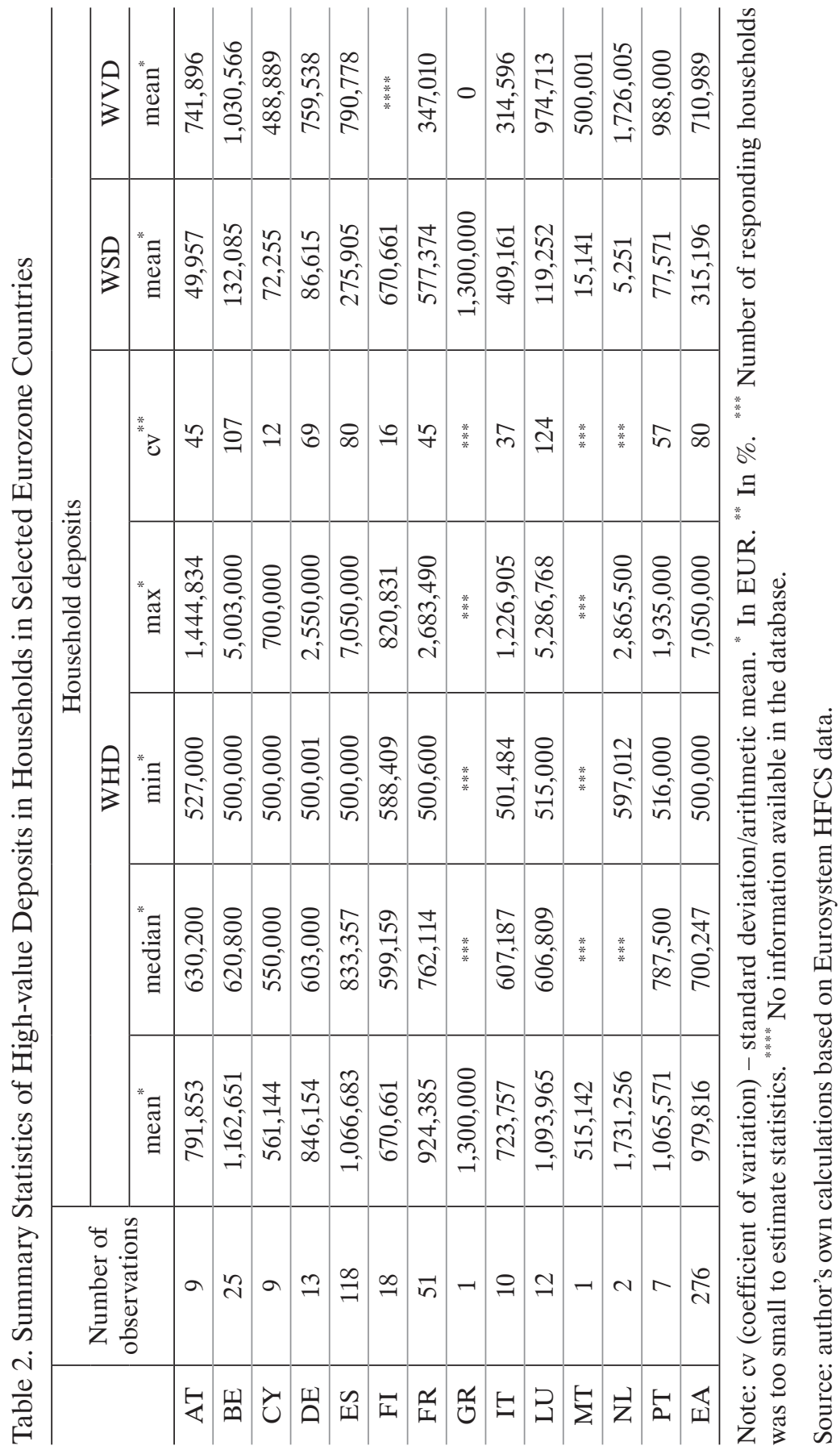




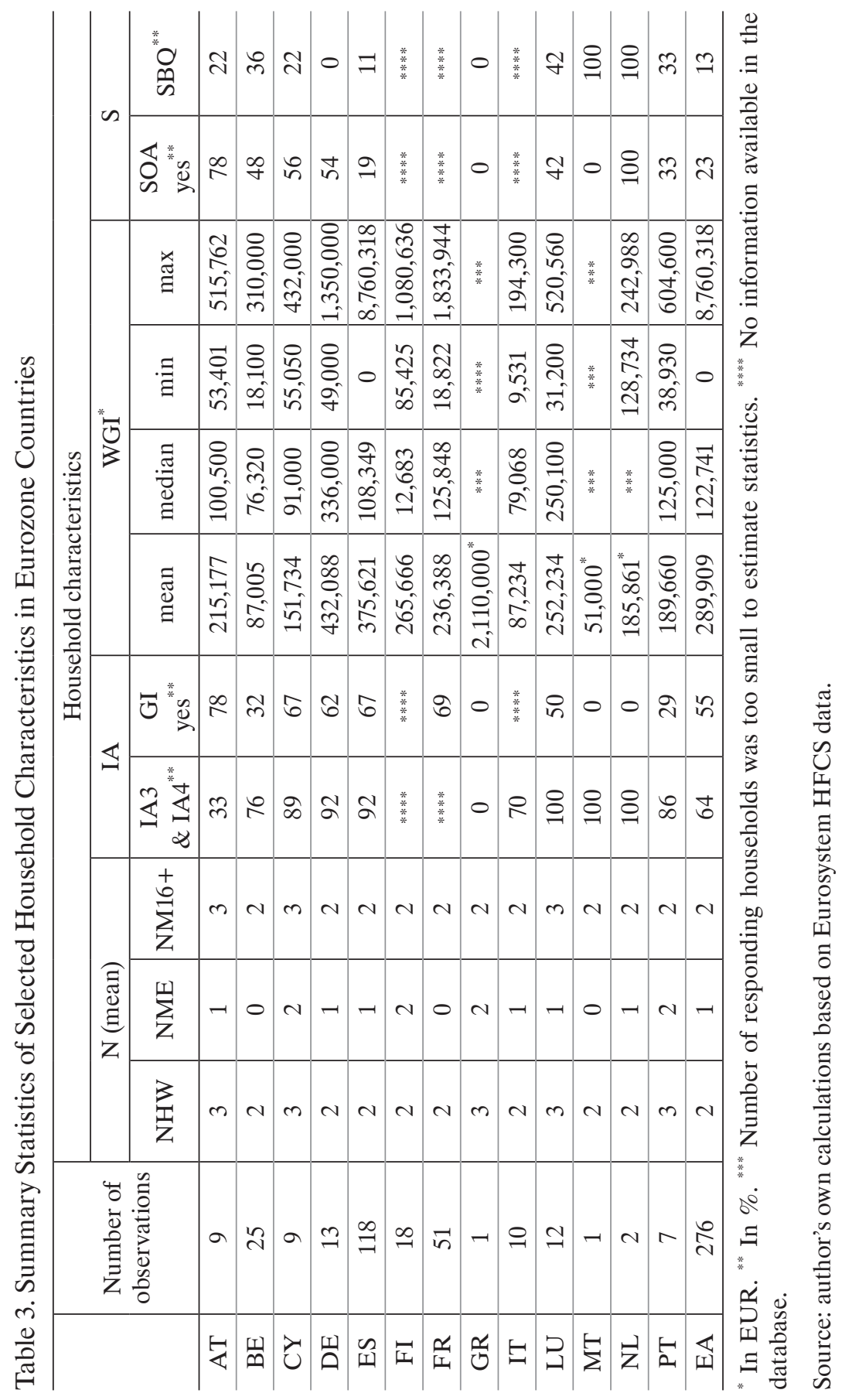




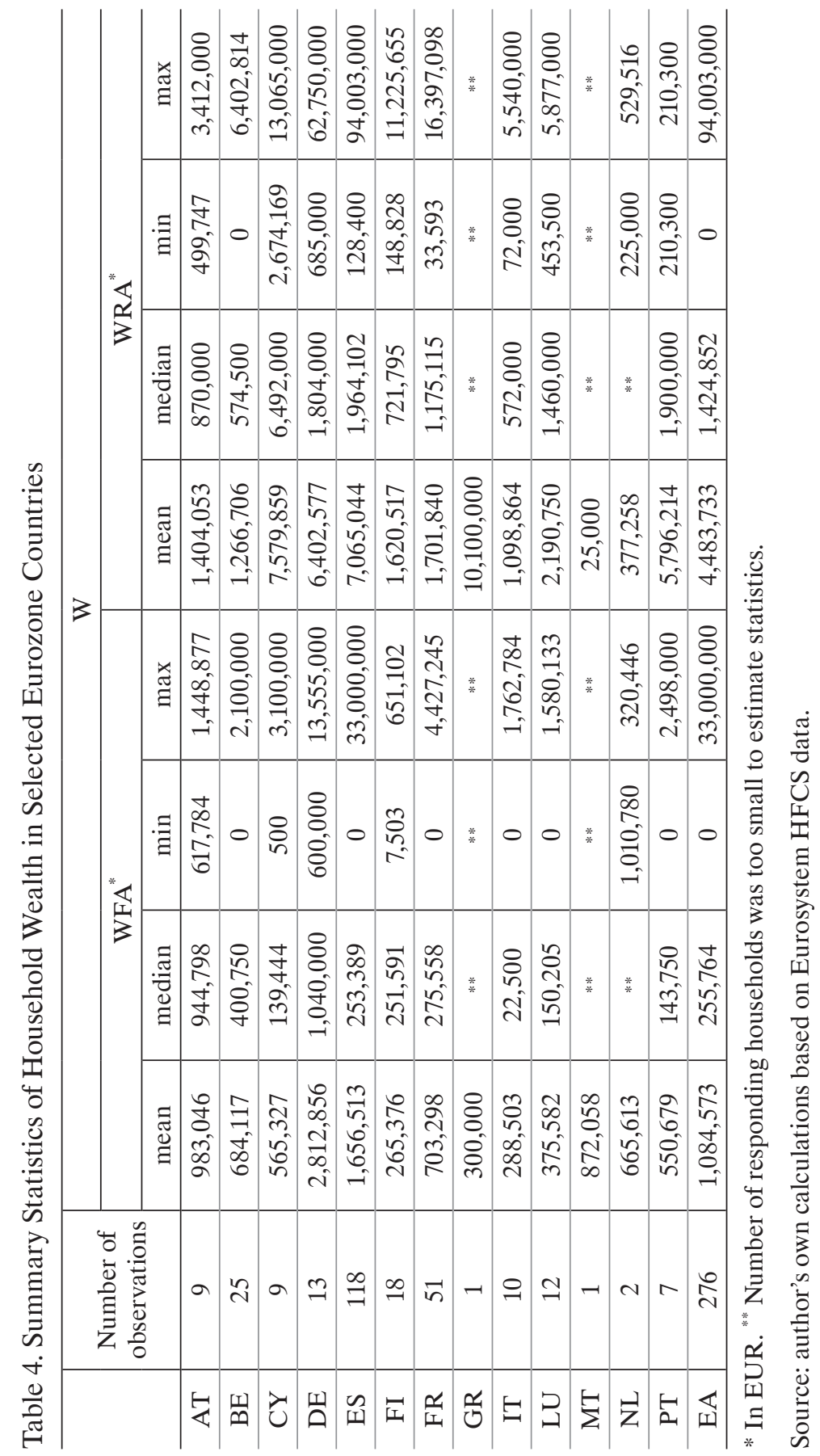


Luxembourg, the Netherlands and Portugal. Other than in the Netherlands and Malta, the average value of real assets exceeded the average value of financial assets (excluding deposits). This may suggest that lower-risk investment in real estate, vehicles or valuables - rather than in riskier mutual funds, bonds or publicly-traded shares - was the priority of households holding high-value deposits. The low-volatility of high-value deposits over the long term would appear to be confirmed by the average age of the reference persons and the reasons for saving that were most often given. The age of the reference persons was 49-66 in almost all of the countries ${ }^{4}$ and, following modifications adopted in recent years, was lower than the retirement age.

The first part of the study demonstrated that the role of high-value deposits in the funding of credit institutions was based on individuals at the domestic level. Furthermore, some of the characteristics of households suggested that this role was relatively stable. Insofar as it may prevent credit institutions from treating the deposits as stable and compel a report of reduced stability of funding to be submitted, the implementation of a uniform threshold of EUR 500,000 may become a burden in countries where high-value deposits account for the greatest proportion of total deposits.

The priority of the second part of the study was to identify sets of common features influencing the probability that a euro area household will possess a high-value deposit. These features can also be understood as ones that affect the propensity to hold a large deposit (Ulman 2011).

The insufficient number of households with high-value deposits in some of the national samples forced the removal from the study of countries with less than nine such cases. A group of nine euro area countries, made up of Austria, Belgium, Cyprus, Germany, Spain, Finland, France, Italy and Luxembourg, remained to be analysed.

The study implemented four versions of the logit model, in which the potential factors describing the probability that a euro area household will possess a high-value deposit were:

1. WNW LOW, WNW HIGH - highlighting the significance of net wealth;

2. WNW LOW, WNW HIGH, WGI LOW, WGI HIGH, A LOW, AT, BE, CY, ES, FI, FR, IT, LU - taking account of net wealth and gross annual

${ }^{4} \mathrm{AT}-51, \mathrm{BE}-65, \mathrm{CY}-58, \mathrm{DE}-64, \mathrm{ES}-66, \mathrm{FI}-59, \mathrm{FR}-71, \mathrm{GR}-41, \mathrm{IT}-60, \mathrm{LU}-61, \mathrm{MT}-$ no data available, NL $-71, \mathrm{PT}-63$. 
income (the main driver of net wealth), the lowest and highest values for the age for reference persons, and country affiliation;

3. WRA LOW, WRA HIGH, WFA LOW, WFA HIGH, A LOW, A HIGH, AT, BE, CY, ES, FI, FR, IT, LU - this is a modification of version 2 that refers to age, country of residence ${ }^{5}$, and to real and financial assets instead of net wealth and gross income;

4. MEM 16+, ETR, MAR, GMA, A LOW, A HIGH, AT, BE, CY, ES, FI, FR, IT, LU - referring to the socio-demographic features of a household and the country that it is in ${ }^{6}$.

The first version of the logit model was the simplest. It tested the influence of household net wealth on the probability that a household would possess a high-value deposit. The WNW HIGH appeared as a statistically significant explanatory variable (Table 5). A household's propensity to possess a high-value deposit increased when it appeared in the highest range for net wealth. This indicates that a way of living that places a high value on asset collection, while being wary of consumption and debt, was the favoured tendency. It can also be concluded that high-value deposits were an attribute of the most affluent households.

Table 5. Summary of Logistic Regression Analysis for Variables Predicting the Incidence of High-value Deposits in Households (Version 1)

\begin{tabular}{c|c|c|c|c}
\hline & $B$ & $S E B$ & $t(517)$ & $p$-value \\
\hline Constant & -1.0312 & 0.1214 & -8.4917 & 0.0000 \\
\hline WNW HIGH & 4.2386 & 0.4043 & 10.4848 & 0.0000 \\
\hline
\end{tabular}

Odds ratio $=69.31$; correctly classified households $-81.32 \%$; chi-square $(11)=272.34$; $p<0.0000$

Source: author's own calculations based on Eurosystem HFCS data.

The odds ratio $^{7}$ confirmed that the classification of households in the analysed category was more precise than a random selection (the probability of correctly classifying households by this model was 69.31 times higher than of incorrectly classifying them). More than $80 \%$ of households were correctly classified. The likelihood ratio (LR) Chi-Square test confirmed the significant influence on the propensity to possess a high value deposit of

\footnotetext{
${ }^{5}$ Germany was the base for comparison.

${ }^{6}$ See footnote 5 .

7 The odds ratio is defined as a multiplication of correctly classified observations in relation to a multiplication of incorrectly classified ones, with a given vector $x_{i}$ of explanatory variables.
} 
the variable under consideration and thus rejected the hypothesis that such an effect was absent.

The second version of the logit model, which employed a set of potential explanatory variables that included net wealth, gross income (the primary driver of net wealth), age of reference person and country of residence, confirmed the conclusions of the first. It was found that the propensity to possess a high-value deposit was weakest among households with low gross income and low net wealth. Whereas the probability of holding a high-value deposit decreased significantly where the reference persons were young, it increased where the factors of high net wealth and high gross income were present. Assuming that other independent variables hold constant, high-value deposits were more frequent in Spanish, Belgian and Austrian households than in those of the remaining countries analysed. It can be stated that the wealthiest households, that is, those in Spain, Belgium and Austria, whose reference persons were 51 years old, had the strongest propensity to possess high-value deposits. The results for version 2 of the logit model are presented in Table 6.

Table 6. Summary of Logistic Regression Analysis for Variables Predicting the Incidence of High-value Deposits in Households (Version 2)

\begin{tabular}{l|c|c|c|c}
\hline & $B$ & $S E B$ & $t(517)$ & $p$-value \\
\hline Constant & -0.0767 & 0.2754 & -0.2787 & 0.7806 \\
\hline WNW HIGH & 2.4103 & 0.4481 & 5.3788 & 0.0000 \\
\hline WNW LOW & -27.6137 & 5530.3410 & -0.0050 & 0.9960 \\
\hline WGI HIGH & 0.8041 & 0.3853 & 2.0869 & 0.0374 \\
\hline WGI LOW & -1.3380 & 0.4250 & -3.1485 & 0.0017 \\
\hline A LOW & -1.3665 & 0.3963 & -3.4483 & 0.0006 \\
\hline ES & 1.5464 & 0.4118 & 3.7554 & 0.0002 \\
\hline BE & 2.1583 & 0.6625 & 3.2576 & 0.0012 \\
\hline AT & 3.0382 & 1.2213 & 2.4877 & 0.0132 \\
\hline
\end{tabular}

Odds ratio $=61.63$; correctly classified households $-88.68 \%$; chi-square $(8)=482.67$; $p<0.0000$

Source: author's own calculations based on Eurosystem HFCS data.

In this version, the odds ratio confirmed that the classification of households was better than a random classification with regard to the presented categories. More than $90 \%$ of households were correctly classified. The likelihood ratio (LR) Chi-Square test confirmed that the 
set of variables under consideration had a significant influence on the propensity of households to hold high-value deposits. The hypothesis of the absence of such effects was thus rejected.

It was found in the third version of the logit model that not all of the potential explanatory variables (components of net wealth: real and financial assets excluding deposits) entered the model. Only WRA HIGH, WRA LOW, WFA HIGH, A LOW, ES, BE, and AT were statistically significant. The results are set out in Table 7. It should be noted that the dummies indicated that the same countries of residence as in version 2 had a positive impact on propensity to hold a high-value deposit. This means that the probability of possessing a high-value deposit appeared to be greater in those countries than in the remaining member states. The same conclusion could be drawn from the WRA HIGH and WFA HIGH variables. The propensity to possess a high-value deposit increased when a household had high real and financial assets. Conversely, if households did not tend to accumulate real assets, the probability of holding a high-value deposit decreased. Explanatory variable A LOW demonstrated that the willingness to possess high-value deposits among young reference persons was lower than in the other groups. This version of the logit model told us that real and financial assets in the highest range of classification, reference persons aged over 50 and residence in Spain, Belgium or Austria were the variables most strongly related in the euro area to holding high-value deposits. The results are set out in Table 7.

Table 7. Summary of Logistic Regression Analysis for Variables Predicting the Incidence of High-value Deposits in Households (Version 3)

\begin{tabular}{l|c|c|c|c}
\hline & $B$ & $S E B$ & $t(517)$ & $p$-value \\
\hline Constant & -0.8077 & 0.2463 & -3.2798 & 0.0011 \\
\hline WRA HIGH & 1.9047 & 0.3499 & 5.4434 & 0.0000 \\
\hline WRA LOW & -1.5571 & 0.3432 & -4.5367 & 0.0000 \\
\hline WFA HIGH & 1.9627 & 0.3263 & 6.0149 & 0.0000 \\
\hline A LOW & -1.4526 & 0.3345 & -4.3426 & 0.0000 \\
\hline ES & 1.2556 & 0.3292 & 3.8140 & 0.0002 \\
\hline BE & 1.8107 & 0.5309 & 3.4104 & 0.0007 \\
\hline AT & 1.5036 & 0.6419 & 2.3425 & 0.0195 \\
\hline
\end{tabular}

Odds ratio $=49.39$; correctly classified households $-87.52 \%$; chi-square $(7)=379.25$; $p<0.0000$

Source: author's own calculations based on Eurosystem HFCS data. 
As in previous versions, the odds ratio informed us that better results were obtained from households that had been classified rather than randomly classified. The probability of carrying out a correct classification of households based on this model was 49 times higher than of carrying out an incorrect one. Almost $90 \%$ of households were classified correctly. The likelihood ratio (LR) Chi-Square test confirmed that the set of variables under consideration had a significant influence on the propensity of households to hold high-value deposits and rejected the hypothesis that such effects were absent. It can therefore be concluded that all of the household characteristics implied in the model - real and financial assets in the highest range of classification, reference persons aged over 50 and residence in Spain, Belgium or Austria - had a significant impact on the propensity to possess high-value deposits in the area analysed.

The fourth version concerned only the impact of socio-demographic features on the willingness of households to hold high-value deposits. The following potential explanatory variables were statistically significant: NM16+, ETR, LSR, GMA, A LOW, A HIGH, ES, AT, BE, LU, CY, and FR. It should be noted that the dummies for these countries of residence had a positive impact on the probability that a household would possess a high-value deposit ${ }^{8}$. This means that the likelihood of possessing a high-value deposit was greater than in Germany, Finland and Italy. Because there was a greater chance that more of its members would be in employment, the probability of possessing a high-value deposit was boosted when the number of household members aged 16 or over was greater. The propensity to possess a high-value deposit also increased if the gender of the household's reference person was male and that person was at least 65 years old. Where the reference persons were young, though, the probability of holding a high-value deposit was lower. The probability was higher where reference persons had completed tertiary education. The propensity to hold high-value deposits among retired reference persons was lower than for groups belonging to other employment classifications. This version of the logit model told us that households with a greater number of members aged over 16 who are well-educated, male, aged over 65 and still in employment were most likely to hold high-value deposits. The results of the analysis are presented in Table 8 .

The odds ratio confirmed that the classification of households into the listed categories yielded better results than random classification. 
The probability of carrying out a correct classification of households by this model was 16 times greater than of performing an incorrect classification. Eighty per cent of households were classified correctly. The likelihood ratio (LR) Chi-Square test confirmed that the set of variables under consideration had a significant influence on the propensity of households to hold high-value deposits and rejected the hypothesis that such effects were absent. In conclusion, the socio-demographic features of households examined in this version of the model had a significant influence on the willingness of euro area households to hold high-value deposits.

Table 8. Summary of Logistic Regression Analysis for Variables Predicting the Incidence of High-value Deposits in Households (Version 4)

\begin{tabular}{l|c|c|c|c}
\hline & $B$ & $S E B$ & $t(517)$ & $p$-value \\
\hline Constant & -2.7030 & 0.4882 & -5.5377 & 0.0000 \\
\hline ES & 1.9893 & 0.3242 & 6.1346 & 0.0000 \\
\hline AT & 2.3697 & 0.6077 & 0.8997 & 0.0001 \\
\hline BE & 1.7913 & 0.4772 & 3.7534 & 0.0002 \\
\hline CY & 1.4646 & 0.3345 & 1.9873 & 0.0473 \\
\hline FR & 0.6655 & 0.3137 & 2.1215 & 0.0343 \\
\hline LU & 2.1608 & 0.6735 & 3.2084 & 0.0014 \\
\hline NM16+ & 0.5087 & 0.1554 & 3.2719 & 0.0011 \\
\hline LSR & -0.9675 & 0.3664 & -2.6401 & 0.0085 \\
\hline GMR & 1.6854 & 0.2493 & 6.7602 & 0.0000 \\
\hline A LOW & 0.6954 & 0.2469 & 2.8121 & 0.0051 \\
\hline A HIGH & -2.2266 & 0.3507 & -6.3495 & 0.0000 \\
\hline
\end{tabular}

Odds ratio $=16.00$; correctly classified households $-80.00 \%$; chi-square $(12)=272.41$; $p<0.0000$

Source: author's own calculations based on Eurosystem HFCS data.

Though all of the versions of the logit model identified characteristics of euro area households likely to possess high-value deposits, it was difficult to point to the one with the best fit in the statistical sense: they all described the problem very well and from different perspectives. The results confirm the major impact of household wealth on the probability of holding a high-value deposit. Versions two, three and four detected that the youngest age category had a negative impact, and the two older categories a positive impact, on the propensity to hold high-value deposits. Of the countries under 
consideration, it was found that the households of Belgium, Austria and Spain had a significantly stronger propensity to possess high-value deposits. Version four of the logit model told us that households with the bracketed socio-demographic characteristics (a greater number of members aged over 16 who are well-educated, male, aged over 65 and still in employment) were most likely to hold high-value deposits.

\section{Conclusions}

The last financial crisis revealed the importance of stable funding if credit institutions are to be resilient and able to dispose of liquidity shocks. The current EU regulations describe household deposits of up to EUR 500,000 as stable. As they may impose unnecessary limits in countries where funding is reported as stable by supervisory authorities, such precise guidelines may, however, prove ineffective. The uniform threshold may thus become merely a needless benchmark serving only to make the regulation more complicated.

The first part of the study identified considerable diversification of high-value deposits in the households of the group of countries analysed. The proportion of respondents who declared that they held them was small: no greater than $2 \%$. In some member states, however, the impact of high-value deposits on the overall total was significant. In Spain, for example, high-value deposits constituted $41.3 \%$ of total household deposits, while they made up $25.9 \%$ of total household deposits in Belgium and $22.7 \%$ in Luxembourg. The scale of these shares in funding did not imply, though, that household deposits were of poor quality. Particular features of households and reference persons, such as attitudes to financial risk, saving aims, a focus on real rather than financial assets, the prioritising of deposits among financial assets and the age of the reference persons, suggested instead that high-value deposits were of a long-term nature.

The second part of the study, which presented certain sets of features thought likely to increase the propensity of euro area households to possess high-value deposits, clearly demonstrated the significance of household wealth and socio-demographic characteristics for the occurrence of this propensity. Net wealth and its components appeared as features of primary importance, which leads to the conclusion that a style of life that places great value on accumulating financial and real assets was responsible for the availability of large deposits for credit institutions. The tendency to hold high-value deposits was relatively low among households with young 
reference persons. However, the need to possess large deposits in the other age subgroups may have been caused by the decreasing incomes that characterise later life. The logit model informed us that households in Belgium, Spain and Austria had a greater propensity, or capacity, to accumulate high-value deposits. It should be noted that the euro area states identified in the first part of the study were those whose credit institutions held the greatest amount of high-value deposits as a proportion of total household deposits. It is assumed that as a consequence the EUR 500,000 threshold may have a more negative influence on the funding stability of Belgian, Spanish and Austrian entities than it does on credit institutions in the remaining states.

\section{Bibliography}

Acharya, V., Almeida, H. and Campello, M. (2013) "Aggregate Risk and the Choice between Cash and Lines of Credit". The Journal of Finance 68 (5): 2059-2116, https:// doi.org/10.1111/jofi.12056.

Acharya, V. and Mora, N. (2012) "Are Banks Passive Liquidity Backstops? Deposit Rates and Flows During the 2007-2009 Crisis". NBER Working Paper No. 17838, http:// www.nber.org/papers/w17838.

Acharya, V. and Mora, N. (2015) "A Crisis of Banks as Liquidity Providers". The Journal of Finance 70 (1): 1-43, https://doi.org/10.1111/jofi.12182.

BCBS (2010) Basel III: A Global Regulatory Framework for More Resilient Banks and Banking Systems. Basel: Bank for International Settlements.

BCBS (2013) Basel III: The Liquidity Coverage Ratio and Liquidity Risk Monitoring Tools. Basel: Bank for International Settlements.

Borio, C. (2009) “Ten Propositions about Liquidity Crises”. BIS Working Paper No. 293. Basel: Bank for International Settlements, pp. 1-21.

Brown, M., Guin, B. and Morkoetter, S. (2013) "Deposit Withdrawals from Distressed Commercial Banks". Swiss Institute of Banking and Finance Working Papers on Finance No. 19. St. Gallen: Swiss Institute of Banking and Finance, pp. 1-33.

Cussen, M., O'Leary, B. and Smith, D. (2012) "The Impact of the Financial Turmoil on Households: A Cross Country Comparison”. Central Bank of Ireland Quarterly Bulletin 2 (April): 78-98.

Diamond, D. W. and Rajan, R. G. (2001) "Banks and Liquidity". American Economic Review 91 (2): 422-25.

Du Caju, P. (2013) "Structure and Distribution of Household Wealth: An Analysis Based on the HFCS". National Bank of Belgium Economic Review 9: 41-62.

EBA (2013a) "Guidelines on Retail Deposits Subject to Different Outflows for Purposes of Liquidity Reporting under Regulation (EU) No 575/2013 on Prudential Requirements for Credit Institutions and Investment Firms and Amending Regulation (EU) No 648/2012 (Capital Requirements Regulation - CRR)”. London: European Banking Authority. 
EBA (2013b) "EBA Discussion Papers on Defining Liquid Assets in the LCR under the Draft CRR and on Retail Deposits Subject to Higher Outflows for the Purposes of Liquidity Reporting". London: European Banking Authority.

ECB (2013) "The Eurosystem Household Finance and Consumption Survey - Results from the First Wave". ECB Statistics Paper Series 2 (April): 1-112.

EU (1994) "Directive 94/19/EC of the European Parliament and of the Council of 30 May 1994 on Deposit-Guarantee Schemes", OJ L 135, 31 May 1994.

EU (2013a) "Directive 2013/36/EU of the European Parliament and of the Council of 26 June 2013 on Access to the Activity of Credit Institutions and the Prudential Supervision of Credit Institutions and Investment Firms, Amending Directive 2002/87/ EC and Repealing Directives 2006/48/EC and 2006/49/EC”, OJ L 176, 27 June 2013.

EU (2013b) "Regulation (EU) No 575/2013 of the European Parliament and of the Council of 26 June 2013 on Prudential Requirements on Credit Institutions and Investment Firms and Amending Regulation (EU) No 648/2012, OJ L 176, 27 June 2013.

EU (2015) "Commission Delegated Regulation (EU) 2015/61 of 10 October 2014 to Supplement Regulation (EU) No 575/2013 of the European Parliament and the Council with Regard to Liquidity Coverage Requirement for Credit Institutions", OJ L 11, 17 January 2015.

EU (2014) "Directive 2014/49/EU of 16 April 2014 on Deposit-Guarantee Schemes", OJ L 173, 12 June 2014.

Gatev, E., Schuermann, T. and Strahan, P. (2009) "Managing Bank Liquidity Risk: How Deposit-Loan Synergies Vary with Market Conditions". Review of Financial Studies 22 (3): 995-1020, https://doi.org/10.1093/rfs/hhm060.

Huang, R. and Ratnovski, L. (2011) "The Dark Side of Bank Wholesale Funding”. Journal of Financial Intermediation 20 (2): 248-63, https://doi.org/10.1016/j.jfi.2010.06.003.

Karas, A., Pyle, W. and Schoors, K. (2013) "Deposit Insurance, Banking Crises, and Market Discipline: Evidence from a Natural Experiment on Deposit Flows and Rates". Journal of Money, Credit and Banking 45 (1): 179-200, https://doi.org/10.1111/ j.1538-4616.2012.00566.x.

Maddala, G. S. (2006) Ekonometria. Warszawa: Wydawnictwo Naukowe PWN.

Mody, A. and Sandri, D. (2011) "The Eurozone Crisis: How Banks and Sovereigns Came to be Joined at the Hip". IMF Working Paper No. 11 (269), Washington, DC: International Monetary Fund, pp. 1-33.

Pennacchi, G. (2006) "Deposit Insurance, Bank Regulation, and Financial System Risks". Journal of Monetary Economics 53 (1): 1-30, https://doi.org/10.1016/ j.jmoneco.2005.10.007.

Podolec, B., Ulman, P. and Wałęga, A. (2008) Aktywność ekonomiczna a sytuacja materialna gospodarstw domowych [Economic activity and the material situation of households]. Kraków: Wydawnictwo Uniwersytetu Ekonomicznego w Krakowie.

Teppa, F., Porpiglia, A., Ziegelmeyer, M., Le Blanc, J. and Zhu, J. (2015) "Household Saving Behaviour and Credit Constraints in the Euro Area". ECB Working Paper No. 1790. Luxembourg: Publications Office, pp. 1-62.

Ulman, P. (2011) Sytuacja ekonomiczna osób niepetnosprawnych $i$ ich gospodarstw domowych $w$ Polsce [The economic situation of disabled people and their households in Poland]. Zeszyty Naukowe - Seria specjalna: Monografie nr 199. Kraków: Wydawnictwo Uniwersytetu Ekonomicznego w Krakowie. 


\section{Abstract}

\section{Jakość dużych depozytów detalicznych i determinanty ich występowania w krajach strefy euro}

W artykule zaprezentowano jedną z regulacyjnych kategorii depozytów detalicznych - tzw. duże depozyty gospodarstw domowych i podjęto próbę oceny ich wrażliwości na odpływ. W pracy opisano także czynniki determinujące skłonność gospodarstw domowych do posiadania takich aktywów.

Analize przeprowadzono na podstawie danych jednostkowych o gospodarstwach domowych pochodzących z bazy Eurosystemu Household Finance and Consumption Survey. W celu identyfikacji determinant występowania dużych depozytów zastosowano metodę regresji logistycznej. Ze względu na fakt, że depozyty należące do opisywanej kategorii stanowią rzadką cechę gospodarstw domowych, badanie przeprowadzono na próbie zbilansowanej, zgodnie z podejściem proponowanym przez G. S. Maddalę.

Uzyskane wyniki wskazują na zróżnicowane udziały dużych depozytów w ogóle depozytów deklarowanych przez gospodarstwa domowe w poszczególnych krajach strefy euro. Ponadto pozwoliły one określić cechy gospodarstw domowych odnoszące się do sytuacji finansowej oraz cech społeczno-demograficznych, które istotnie wpływają na prawdopodobieństwo posiadania dużych depozytów.

Słowa kluczowe: depozyty gospodarstw domowych, duże depozyty, normy płynności, źródła finansowania banków. 